research infrastructures. It says that universities have a duty to preserve collections that it describes as being 'in critical condition' and make them available to internal and external researchers - and to integrate them as appropriate into teaching programmes.

The council also details how this should be done. Universities, it says, together with Germany's research museums and the country's main granting agency, the DFG, should develop criteria to assess the scientific merit of a collection. These criteria should then be applied in a hard-nosed fashion so that inferior collections are closed or transferred elsewhere. Furthermore, historic scientific collections in universities should be allocated the space they need, including a room for researchers to work on them and for exhibitions.

This prioritization is important. Historic objects frequently turn out to have great - often unexpected - value for cutting-edge research. Well-preserved old bones, for example, are a treasure trove for modern palaeontologists wielding new DNA-based analytical technologies. Old herbaria can similarly feed the curiosity of today's plant geneticists. Historic collections can also be unique resources for social scientists, particularly science historians. So the Wissenschaftsrat's endorsement of their fundamental value is extremely welcome.

But will the recommendations be taken up? Most probably yes. The Wissenschaftsrat has serious clout because it comprises representatives from both the federal and state governments, as well as scientists. Its procedures are systematic and its analyses are thorough. It makes no recommendations that its members know they will not be able to pay for. It could, however, take some time for the recommendations to be implemented.

In the case of scientific collections, the Wissenschaftsrat proposes that the federal government issues a call for proposals for a five-year project to coordinate the efforts of universities to save their collections.

Scientists at German universities - which are funded by state governments, and constitutionally banned from receiving infrastructure funding from the federal government - should find short-term grants from research agencies or foundations to upgrade, restore and make their collections available. The universities themselves should then

"The initiative is winning admiration for its long-term vision." provide overheads for ensuring that the collections are looked after in the long-term, a sum that the Wissenschaftsrat says should be modest.

These recommendations did not emerge from a vacuum. In 2004, the DFG supported a five-year project to identify and catalogue collections in German universities. It identified more than a thousand, of which nearly 300 were shown to have been lost or destroyed. Herbaria that were once state-of-the-art, for example, were confined to dusty cellars or stuffy attics when classical botanics fell out of research fashion.

This DFG programme won the admiration of scientists in many countries that still have no national catalogue of the treasures hidden in their own universities and no systematic way of preparing one. The Wissenschaftsrat's initiative is now winning admiration for its longterm vision and political commitment.

There will certainly be battles to come. Simply saying that space should be made available for collections isn't helpful if there is genuinely no space to be had, for example. But the value that the Wissenschaftsrat now places on collections should make such battles easier to win. Research organizations in other countries should look to see if they could follow its lead. A collection deemed scientifically valuable doesn't need to be as peculiar as Scarpa's head to make it worth preserving, but it needs the same protections and accessibility.

\section{Tough on truth}

\section{The Global Fund should be praised for coming clean about fraud by grant recipients.}

\section{"F} raud plagues global health fund," screamed the title of an article published last month by the Associated Press, which alleged that: "A $\$ 21.7$ billion development fund backed by celebrities and hailed as an alternative to the bureaucracy of the United Nations sees as much as two-thirds of some grants eaten up by corruption, The Associated Press has learned."

Journalistic scrutiny of aid is welcome and revelations of widespread and large-scale fraud by recipients of grants from the Global Fund to Fight AIDS, Tuberculosis and Malaria would be a big deal. The fund, created by the highly industrialized countries of the G8 forum in 2002, now accounts for one-quarter of all international financing to fight AIDS, two-thirds of that for tuberculosis, and three-quarters of that for malaria. But despite using the phrase "has learned" - journalist shorthand for a scoop - the Associated Press (AP) article's central claims contained no new revelations. The frauds mentioned - involving grants to Mali, Mauritania, Djibouti and Zambia — had already been made public by the fund itself.

The sums involved in the reported fraud cases amount to US\$39 million, of $\$ 13$ billion that the fund has disbursed, but other fraud cases have no doubt so far gone undetected. Although any corruption is too much, to keep it down to these levels would be an achievement, given the realities of putting large amounts of money into any country or project, not least those where corruption can be rife.

Nonetheless, Sweden, Germany and Ireland have responded with suggestions they may suspend their pledges to the fund for the period covering 2011-13. As fund members they are well aware of how it handles corruption, so their response is probably partly a reaction to the wide publicity that the AP article received in the international media, and the sensationalist and exaggerated claims about the scale of the problem - no government, accountable as it is to taxpayers, wants to be seen as lax on corruption. As Nature went to press, reports suggested that funding from these countries would be restored, while Sweden has also since said that it is happy with the way the Global Fund is dealing with the problem.

The reputation of the fund - which by its own estimates saved more than 4.9 million lives by 2009 - has been unfairly tarnished, and its fund-raising efforts perhaps hampered at a time when the economic crisis is already making donors reconsider the size of their contributions.

When it comes to being transparent over problems of corruption in recipient countries the Global Fund has been far better than most aid donors or agencies. It has openly tackled corruption - with a 'zero tolerance' policy, suspending grants at the first whiff of wrong-doing, and working with recipient countries to bring fraudsters to justice and recover what misdirected money it can. Could it do more? Yes: for example, by strengthening oversight further. But it is already well down the road to effectively tackling corruption.

The same cannot be said for many of the alphabet-soup of aid agencies, which choose not to publicise their own uncovered fraud cases, perhaps out of fear of damaging their image, and losing donors. Several observers have been quick to point out that if the AP article has an upside, it is to have drawn renewed attention to fraudulent use of funds by such agencies. The fight against aid corruption has generally improved markedly since the 1990s, but many agencies still fall far below the high bar set by the Global Fund. Meanwhile, astonishingly, the fund's own fraud investigations have been hampered because the $\rightarrow$ NATURE.COM To comment online, click on Editorials at: go.nature.com/xhunqu
United Nations Development Programme, which manages some of its grants, has refused to allow the fund access to its records. Scrutiny should be welcomed, but honesty should not carry so high a price. $\square$ 